\title{
Surface Wettability and Roughness of 11 Amazonian Tropical Hardwoods
}

\author{
Marcela Regina Siqueira Amorim¹, Patrícia Gomes Ribeiro ${ }^{1}$, \\ Sabrina Andrade Martins ${ }^{1}$, Cláudio Henrique Soares Del Menezzi ${ }^{1}$, \\ Mário Rabelo de Souza ${ }^{2}$ \\ ${ }^{1}$ Departamento de Engenharia Florestal, Universidade de Brasília - UnB, Brasília/DF, Brasil \\ ${ }^{2}$ Laboratório de Produtos Florestais, Serviço Florestal Brasileiro - SFB, Brasília/DF, Brasil
}

\begin{abstract}
The purpose of this study was to evaluate the wettability and surface roughness of 11 Amazonian hardwoods. Surface roughness was evaluated by a profilometer, while wettability was measured by a goniometer. Distillated water and phenol-formaldehyde were employed to study wood wettability. A $10-\mu \mathrm{L}$ drop was placed on the wood surface and the contact angle was measured every 2 seconds for 120 seconds. The Virola michelii and Trattinnickia burserifolia wood specimens analyzed presented different roughness values according to the surface evaluated, radial or tangential. Regarding wettability, Virola michelii wood showed the lowest water contact angle on the tangential surface, while the radial surface presented better wettability for phenol-formaldehyde. The wettability of the species studied was not clearly affected by surface roughness, which depends on wood density.
\end{abstract}

Keywords: wettability, contact angle, surface roughness.

\section{Molhabilidade e Rugosidade Superficial de 11 Madeiras Tropicais Amazônicas}

\section{RESUMO}

O objetivo do presente trabalho foi avaliar a rugosidade e a molhabilidade de 11 espécies de madeiras. A rugosidade da superfície das madeiras foi analisada usando-se o rugosímetro. Para analisar a molhabilidade, foram realizadas medições do ângulo de contato pela gota séssil com o uso de um goniômetro. Água destilada e adesivo fenólico foram os líquidos empregados, sendo que o volume da gota depositada sobre o material foi de $10 \mu \mathrm{L}$ e as medições realizadas a cada 2 segundos, por um período de 120 segundos. As espécies Virola michelii e Trattinnickia burserifolia apresentaram rugosidade diferente entre as faces radial e tangencial. Em relação à molhabilidade, a espécie Virola michelii apresentou maior molhabilidade na face tangencial para o líquido água, enquanto que para o adesivo fenol-formaldeído a melhor molhabilidade foi na face radial. Nas espécies Brosimum sp. e Chamaecrysta scleroxyllum, a maior molhabilidade se deu na face tangencial. A molhabilidade das espécies estudadas não foi claramente influenciada pela rugosidade da superfície; por outro lado, a mesma variou com o inverso da densidade da madeira.

Palavras-chave: molhabilidade, ângulo de contato, rugosidade superficial. 


\section{INTRODUCTION}

Wood harvesting in the Brazilian Amazon still causes major timber loss, as only $30 \%$ of each $\log$ is actually used (Clement \& Higuchi, 2006). Therefore, it is necessary to develop technologies to increase processing efficiency, aiming to obtain alternative and high-quality products using massive as well as residual wood from industry. Thereunto, aggregating value to final products produced by innovative techniques has become the objective of several studies with respect to adhesion (Santos \& Del Menezzi, 2010), nondestructive evaluation (Del Menezzi et al., 2010; Teles et al., 2011), particleboards manufacturing (Iwakiri et al., 2012), and engineered wood products manufacturing (Teles et al., 2010; Campos et al., 2012) from tropical hardwood. However, as discussed by Shupe et al. (2001), wood surface properties are a key issue in determining the performance of an adhesive. Sinn et al. (2009) presented an interesting review about wood surface properties focusing mainly on surface wettability and roughness.

Wood-based boards are manufactured through the gluing of sheets, boards, slats, strands, or fibers with dimensions and characteristics defined by their end use, and the product characteristics are given by the adhesive bond between the elements (Marra, 1992). The gluing process comprises three stages: surface preparation, adhesive interaction with the wood at molecular level, and solidification (Frihart, 2005). Adhesive penetration in wood is influenced by: i) wood factors - species, anatomy (alignment), wood chemistry (content of extractives, cellulose, hemicelluloses, and lignin), and surface roughness; ii) adhesive factors - type and viscosity; and iii) manufacturing factors - pressure and temperature (Kamke \& Lee, 2007).

Adhesive penetration is also influenced by wood aging, defects, and methods of mechanical processing (such as sandpaper and planer) (Cruz, 2006). Adhesive capacity directly influences the physical and mechanical properties and the endproduct durability. Thus, roughness and wettability variables are used to evaluate wood adhesive capacity. The behavior of the interaction between wood surface and liquids in general can be inferred through the observation of these properties. Wood roughness depends on its cellular structure and on the processing to which it has been submitted. It may be defined in macro, micro, nano, and molecular scales (Piao et al., 2010). The surface may be evaluated by objective parameters such as roughness before and after the finishing process (Malkoçoglu, 2007). According to Lemaster (1999), wood roughness may be evaluated by contact and noncontact profilometers, which are used to evaluate other materials such as metals. The most common technique uses a touch sensor that mechanically measures the surface height throughout a line. From the profile obtained, variables are determined for roughness evaluation. Roughness is closely related to wettability: the higher the roughness, the higher the surface hydrophilicity (Piao et al., 2010).

Wettability means how easily and efficiently some liquid spreads over a solid surface (Gray, 1962). It may be characterized by thermodynamic parameters such as contact angles, surface free energy, and work of adhesion (Wålinder, 2000, 2002). The method of the liquid contact angle with the surface depends on the material roughness, topography, morphology, and chemical composition. A very rough surface may offer resistance to the adhesive penetration due to the presence of air in its cavities (Gray, 1962). Therefore, it is important to know these variables behavior to improve the interaction between wood, finishing, and gluing products, since a surface with high wettability offers high glue line shear resistance (Freeman \& Wangaard, 1960). Studies on tropical wood or hardwood wettability are scarce, but Boehme \& Hora (1996), Kishino \& Nakano (2004), and Buyuksari et al. (2011) can be cited, as well as the studies carried out in Brazil by Soares et al. (2011), Oliveira et al. (2010) and Santos et al. (2012). In this context, the objective of the present work was to evaluate the roughness and wettability of 11 Amazonian hardwoods.

\section{MATERIAL AND METHODS}

\subsection{Woody material}

We made use of 11 Amazonian hardwood specimens from the Tapajós - Arapiuns Extractivist 
Reserve (Table 1), donated by the Federal University of Western Pará (UFOPA). The material is part of the Project UFOPA, developed by the Forest Products Laboratory/Brazilian Forest Service (LFP/SFB). The wood was anatomically identified by comparison with material deposited at the Wood Collection of the Wood Anatomy Sector of the LPF/SFB (Index Xylarium FPBw).

The material was sawed producing 132 specimens (CPs) of $2 \times 2 \times 10 \mathrm{~cm}$ (width $\mathrm{x}$ thickness $\mathrm{x}$ length), which were kept in acclimatized chamber $\left(20^{\circ} \mathrm{C}\right.$; $65 \% \mathrm{RH}$ ) until constant weight was reached. After that, they were measured and weighed to determine the apparent density $\left(\rho_{12}\right)$, according to the COPANT 30:1-004 (1971) norm. The surfaces were flattened by a double side planer (Invicta, Limeira, Brazil) with $3,440 \mathrm{rpm}$ of the blade holder axis. The planer cutting depth was nearly $0.6 \mathrm{~mm}$. This procedure was chosen because it is very common in all kinds of sawmills and therefore, it would be more representative.

\subsection{Roughness}

Roughness was measured on the tangential and radial surfaces using the Surftest SJ - 400 (Mitutoyo, Aurora, USA) hand-held tester, according to JIS B 0601 (2001), with 0.8 -mm cut-off and 8-mm evaluation length. Two measures were performed in each surface in the transverse direction of the wood fibers, accounting for 48 measures per species and 528 in total. The variables evaluated were $R_{\mathrm{a}}, R_{\mathrm{z}}$ and $R_{\mathrm{t}}$, determined according to Equations 1, 2 and 3, respectively (JIS, 2001).

$$
\begin{aligned}
& R_{a}=\frac{1}{N} \sum_{i=1}^{N}\left|Y_{i}\right| \\
& R_{z}=\frac{1}{5} \sum_{i=1}^{S} Y_{p i}+\frac{1}{5} \sum_{i=1}^{S} Y_{v i} \\
& R_{t}=Y_{p}+Y_{v}
\end{aligned}
$$

Where: $\mathrm{R}_{\mathrm{a}}=$ arithmetic mean of the deviations absolute values of the mean line profile; $\mathrm{R}_{\mathrm{z}}=$ sum of the mean height of the five highest peaks of the profile and depth of the five deepest valleys of the profile, measured from a line parallel to the mean line; $R_{t}=$ sum of the height of the profile maximum peak and the depth of the profile maximum valley over the extension evaluated. $\mathrm{Y}_{\mathrm{i}}=$ Profile deviations; $\mathrm{Y}_{\mathrm{pi}}=$ Highest profiles; $\mathrm{Y}_{\mathrm{vi}}=$ Deepest valleys; $\mathrm{Y}_{\mathrm{p}}=$ Highest peak; $\mathrm{Y}_{\mathrm{v}}=$ Deepest valley.

\subsection{Wettability}

For wettability analysis, contact angle measurements in the radial and tangential surfaces were performed by the sessile drop method, using the Krüss DSA30 instrument and the DSA3 software module (Hamburg, Germany). Two liquids were used: distilled water and CR-7010 phenolic adhesive (SI Group Crios, Rio Claro, Brazil). They were diluted at 3\% in distilled water in order to reach the mean viscosity of $400 \mathrm{cP}$ - properties are described in Table 2. The drop deposited over the material presented $10-\mu \mathrm{L}$ volume and the measurements were performed every 2 seconds for 120 seconds. The final

Table 1. Scientific name, botanical family, and common name of the species studied.

\begin{tabular}{lll}
\hline \multicolumn{1}{c}{ Scientific name } & Botanical family & \multicolumn{1}{c}{ Common name } \\
\hline Swartzia laurifoliaBenth. & Leg. Papilionoideae & 'Gombeira' \\
Brosimum sp. $^{1}$ & Moraceae & 'Amapaí' \\
Chamaecrysta scleroxyllum(Ducke) Irwin e Barnaby. & Leg. Papilionoideae & 'Pau santo' \\
Balizia elegans (Ducke) Barneby \& J.W.Grimes. & Leg. Mimosoideae & 'Fava paricá' \\
Virola michelii Heckel. & Myristicaceae & 'Virola' \\
Trattinnickia burserifolia Mart. & Burseraceae & 'Breu amescla' \\
Tachigali myrmecophila (Ducke) Ducke. & Leg. Caesalpinioideae. & 'Tachi preto' \\
Rhodostemonodaphne dioica $(\mathrm{Mez})$ Rohwer. & Lauraceae & 'Louro preto' \\
(= Nectandra dioica Mez) & Vochysiaceae & 'Mandioqueira rosa' \\
Qualea dinizii Ducke. & Combretaceae & 'Cuiarana' \\
Terminalia glabrescens C. Mart. & Burseraceae & 'Breu branco' \\
Protium sagotianum Marchand. & &
\end{tabular}

${ }^{1}$ Identified only until gender level. 
contact angle $\left(\theta_{A}\right)$ was registered after 120 seconds. For each species/liquid, 24 measures of $\theta_{A}$ were made, totaling 264 measures.

\subsection{Image Analysis}

Images with $80 \times$ magnification of the radial and tangential surfaces of the 11 species were obtained. A stereomicroscope Leica model S8APO (Singapure) was used to visualize the surfaces.

\subsection{Statistical Analysis}

At first, data with respect to the 132 CPs were submitted to analysis of variance (ANOVA), followed by Tukey's test at the level of $\alpha=0.05$ to identify statistical differences between the observed variables means $\left(R_{\mathrm{a}}, R_{\mathrm{z}}, R_{\mathrm{t}}\right.$ and $\left.\theta_{\mathrm{A}}\right)$ for the species studied. Moreover, simple linear regression analysis was performed using the variables $R_{\mathrm{a}}, R_{\mathrm{z}}, R_{\mathrm{t}}$ and $\rho_{12}$ as estimators of the final contact angle $\left(\theta_{A}\right)$ for both liquids.

\section{RESULTS AND DISCUSSION}

\subsection{Apparent density}

Table 3 shows the mean values of apparent density of the specimens used in the present study. Within the species studied, there are some with low, average, and high density, ranging from $0.43 \mathrm{~g} . \mathrm{cm}^{-3}$ to $1.2 \mathrm{~g} . \mathrm{cm}^{-3}$.

\subsection{Roughness}

Table 4 shows the roughness mean variables $\left(R_{\mathrm{a}}, R_{\mathrm{z}}\right.$ and $\left.R_{\mathrm{t}}\right)$ for all the species studied in the present work. Differences statistically significant

Table 2. Properties of the phenolic adhesive CR-7010 according to the manufacturer.

\begin{tabular}{|cc|}
\hline Property & CR-7010 \\
\hline Appearance & Red viscous liquid \\
\hline Viscosity $\left(25^{\circ} \mathrm{C}\right)$ & $400-800 \mathrm{cP}$ \\
\hline Content of solids $\left(105^{\circ} \mathrm{C}\right)$ & $48-52 \%$ \\
\hline $\mathrm{pH}$ & $11-13$ \\
\hline Density & $1.20-1.25 \mathrm{~g} \cdot \mathrm{cm}^{-3}$ \\
\hline
\end{tabular}

Source: SI Group Crios (Rio Claro, Brazil). for roughness variables $\left(R_{\mathrm{a}}, R_{\mathrm{z}}\right.$ and $\left.R_{\mathrm{t}}\right)$ among the 11 species studied were observed based on the ANOVA and Tukey's test.

According to this analysis, it can be inferred that the species with the lowest roughness (lowest values of $R_{\mathrm{a}}, R_{\mathrm{z}}$ and $R_{\mathrm{t}}$ ) was Swartzia laurifolia, not only on the radial but also on the tangential face (means $2.45 \mu \mathrm{m}$; $16.1 \mu \mathrm{m} ; 30.3 \mu \mathrm{m})$. The highest radial face roughness was found for Trattinnickia burserifolia with respect to $R_{\mathrm{a}}$ and $R_{\mathrm{t}}$ variables $(7.85 \mu \mathrm{m} ; 68.5 \mu \mathrm{m})$, and for Balizia elegans $(38.4 \mu \mathrm{m})$, Trattinnickia burserifolia $(38.6 \mu \mathrm{m})$, and Tachigali myrmecophila $(37.4 \mu \mathrm{m})$ with respect to $R_{z}$. On the other hand, regarding the tangential face, the highest $R_{\mathrm{a}}$ values were observed for Balizia elegans $(6.47 \mu \mathrm{m})$, Trattinnickia burserifolia $(6.36 \mu \mathrm{m})$, and Tachigali myrmecophila $(6.32 \mu \mathrm{m})$; the highest $R_{\mathrm{z}}$ values were found for Balizia elegans (38.4 $\mu \mathrm{m})$, Trattinnickia burserifolia (38.2 $\mu \mathrm{m})$, Tachigali myrmecophila (38.6 $\mu \mathrm{m})$, and Qualea dinizii $(38.9 \mu \mathrm{m})$; and the highest $R_{\mathrm{t}}$ values were verified for Trattinnickia burserifolia $(65.9 \mu \mathrm{m})$, and Tachigali myrmecophila $(64.1 \mu \mathrm{m})$.

Radial and tangential faces within each species were also comparatively analyzed (Table 4). According to the ANOVA, the species Virola michelii presented significant difference between radial and tangential faces for $R_{\mathrm{a}}$ and $R_{\mathrm{z}}$ variables. $R_{\mathrm{a}}$ was higher on the radial face $(5.1 \mu \mathrm{m} \times 4.5 \mu \mathrm{m})$, while the tangential face presented a higher value than the radial face regarding the $R_{\mathrm{z}}$ variable $(31.7 \mu \mathrm{m} \times 27.8 \mu \mathrm{m})$. Analyzing Virola michelii radial face, presented

Table 3. Specimens apparent density of the species used in the present study.

\begin{tabular}{lcc|}
\multirow{2}{*}{ Species } & \multicolumn{2}{c}{ Density $\left(\mathbf{g} \cdot \mathbf{c m}^{-3}\right)$} \\
\cline { 2 - 3 } & Mean & CV (\%) \\
\hline Balizia elegans & 0.43 & 17.64 \\
Trattinnickia burserifolia & 0.53 & 7.79 \\
Tachiga limyrmecophila & 0.56 & 12.03 \\
\hline Virola michelii & 0.58 & 2.48 \\
\hline Brosimum sp. & 0.61 & 5.83 \\
Qualea dinizii & 0.63 & 6.57 \\
Rhodostemonodaphne dioica & 0.70 & 12.04 \\
Protium sagotianum & 0.71 & 12.36 \\
\hline Chamaecrysta scleroxyllum & 1.00 & 2.75 \\
Terminalia glabrescens & 1.01 & 3.74 \\
Swartzia laurifolia & 1.20 & 8.46 \\
Mean & 0.72 & 8.34 \\
\hline
\end{tabular}


Table 4. Mean values of roughness variables $\left(\mathrm{R}_{\mathrm{a}}, \mathrm{R}_{\mathrm{z}}\right.$ and $\left.\mathrm{R}_{\mathrm{t}}\right)$ obtained through the roughness test.

\begin{tabular}{|c|c|c|c|c|c|c|}
\hline \multirow{2}{*}{ Species } & \multicolumn{2}{|c|}{$R_{\mathrm{a}}(\mu \mathrm{m})$} & \multicolumn{2}{|c|}{$R_{\mathrm{z}}(\boldsymbol{\mu \mathrm { m }})$} & \multicolumn{2}{|c|}{$R_{\mathrm{t}}(\mu \mathrm{m})$} \\
\hline & Rd & Tg & Rd & $\mathrm{Tg}$ & Rd & $\mathrm{Tg}$ \\
\hline S. laurifolia & $\begin{array}{r}2.50^{\mathrm{a}} \\
(0.82)\end{array}$ & $\begin{array}{r}2.41^{\mathrm{a}} \\
(0.75)\end{array}$ & $\begin{array}{l}16.87^{\mathrm{a}} \\
(6.35)\end{array}$ & $\begin{array}{l}15.43^{\mathrm{a}} \\
(3.57)\end{array}$ & $\begin{array}{r}29.87^{\mathrm{a}} \\
(14.61)\end{array}$ & $\begin{array}{r}30.66^{\mathrm{a}} \\
(12.54)\end{array}$ \\
\hline Brosimum sp. & $\begin{array}{l}5.34^{\mathrm{bcd}} \\
(1.26)\end{array}$ & $\begin{array}{c}5.0^{\mathrm{bcd}} \\
(1.16)\end{array}$ & $\begin{array}{l}31.47^{\mathrm{bcd}} \\
(7.37)\end{array}$ & $\begin{array}{l}31.36^{b c} \\
(6.64)\end{array}$ & $\begin{array}{c}49.75^{b c} \\
(16.49)\end{array}$ & $\begin{array}{c}52.47^{\mathrm{bc}} \\
(17.37)\end{array}$ \\
\hline C. scleroxyllum & $\begin{array}{l}4.74^{\mathrm{bc}} \\
(1.11)\end{array}$ & $\begin{array}{c}4.55^{\mathrm{bc}} \\
(0.96)\end{array}$ & $\begin{array}{r}27.37^{b} \\
(4.34)\end{array}$ & $\begin{array}{l}30.13^{b} \\
(7.56)\end{array}$ & $\begin{array}{c}45.04^{\mathrm{ab}} \\
(12.65)\end{array}$ & $\begin{array}{r}49.62^{\mathrm{b}} \\
(12.29)\end{array}$ \\
\hline B. elegans & $\begin{array}{l}6.10^{\text {cde }} \\
(1.74)\end{array}$ & $\begin{array}{r}6.47^{\mathrm{e}} \\
(2.06)\end{array}$ & $\begin{array}{l}38.40 \mathrm{~d} \\
(11.91)\end{array}$ & $\begin{array}{l}38.43 \mathrm{c} \\
(10.74)\end{array}$ & $\begin{array}{c}63.28^{\mathrm{cd}} \\
(20.05)\end{array}$ & $\begin{array}{c}58.12^{\mathrm{bc}} \\
(18.47)\end{array}$ \\
\hline V. michelii & $\begin{array}{l}5.10^{\mathrm{bcdA}} \\
(1.19)\end{array}$ & $\begin{array}{c}4.46^{\mathrm{bcB}} \\
(0.88)\end{array}$ & $\begin{array}{c}27.83^{\mathrm{bB}} \\
(6.03)\end{array}$ & $\begin{array}{l}31.69^{\mathrm{bcA}} \\
(6.79)\end{array}$ & $\begin{array}{c}43.70^{\mathrm{ab}} \\
(15.03)\end{array}$ & $\begin{array}{l}49.84^{\mathrm{b}} \\
(9.28)\end{array}$ \\
\hline T. burserifolia & $\begin{array}{l}7.85 \mathrm{fA} \\
(2.66)\end{array}$ & $\begin{array}{l}6.36 \mathrm{eB} \\
(1.33)\end{array}$ & $\begin{array}{l}38.61 \mathrm{~d} \\
(11.37)\end{array}$ & $\begin{array}{l}38.16 \mathrm{c} \\
(9.00)\end{array}$ & $\begin{array}{l}68.52 \mathrm{~d} \\
(24.01)\end{array}$ & $\begin{array}{l}65.93 c \\
(20.25)\end{array}$ \\
\hline T. myrmecophila & $\begin{array}{c}6.79^{\mathrm{ef}} \\
(1.92)\end{array}$ & $\begin{array}{r}6.32^{\mathrm{e}} \\
(1.39)\end{array}$ & $\begin{array}{c}37.41^{\mathrm{d}} \\
(10.08)\end{array}$ & $\begin{array}{l}38.63^{c} \\
(8.59)\end{array}$ & $\begin{array}{c}62.10^{\mathrm{cd}} \\
(22.94)\end{array}$ & $\begin{array}{c}64.08 \mathrm{c} \\
(17.03)\end{array}$ \\
\hline R. dioica & $\begin{array}{l}5.04^{\text {bcd }} \\
(1.45)\end{array}$ & $\begin{array}{l}5.32^{\text {cde }} \\
(1.63)\end{array}$ & $\begin{array}{l}32.33^{\mathrm{bcd}} \\
(9.81)\end{array}$ & $\begin{array}{c}35.73^{b c} \\
(10.39)\end{array}$ & $\begin{array}{l}55.59^{\mathrm{bcd}} \\
(17.44)\end{array}$ & $\begin{array}{c}60.55^{b c} \\
(13.24)\end{array}$ \\
\hline Q. dinizii & $\begin{array}{l}6.43^{\mathrm{de}} \\
(1.44)\end{array}$ & $\begin{array}{c}5.83^{\mathrm{de}} \\
(1.69)\end{array}$ & $\begin{array}{l}35.79^{\mathrm{cd}} \\
(6.89)\end{array}$ & $\begin{array}{r}38.91^{c} \\
(13.61)\end{array}$ & $\begin{array}{c}61.55^{\mathrm{cd}} \\
(18.08)\end{array}$ & $\begin{array}{c}62.57^{b c} \\
(18.35)\end{array}$ \\
\hline T. glabrescens & $\begin{array}{r}4.46^{\mathrm{b}} \\
(1.02)\end{array}$ & $\begin{array}{c}3.99^{\mathrm{b}} \\
(0.80)\end{array}$ & $\begin{array}{l}28.49^{b c} \\
(6.76)\end{array}$ & $\begin{array}{r}28.51^{\mathrm{b}} \\
(6.22)\end{array}$ & $\begin{array}{c}51.38^{b c} \\
(13.51)\end{array}$ & $\begin{array}{c}49.46^{\mathrm{b}} \\
(11.00)\end{array}$ \\
\hline P. sagotianum & $\begin{array}{l}5.87^{\text {cde }} \\
(1.47)\end{array}$ & $\begin{array}{c}5.53^{\text {cde }} \\
(1.46) \\
\end{array}$ & $\begin{array}{l}35.70^{\mathrm{cd}} \\
(8.23)\end{array}$ & $\begin{array}{l}34.76^{\mathrm{bc}} \\
(8.73) \\
\end{array}$ & $\begin{array}{c}53.84^{\text {bcd }} \\
(11.46) \\
\end{array}$ & $\begin{array}{c}52.91^{\mathrm{bc}} \\
(14.11)\end{array}$ \\
\hline
\end{tabular}

The values in parenthesis represent the standard deviation; means followed by the same letter do not statistically differ from each other by Tukey's test $(p \leq 0.05)$. Lower case letters regard the analysis between species and capital letters regard the analysis between the radial and tangential faces within each species. $\mathrm{Ra}=$ arithmetic mean of the absolute values of the average line deviations; $\mathrm{Rz}$ = sum of the mean height of the five highest peaks of the profile and the depth of the five deepest valleys of the profile, measured from a line parallel to the average line; $\mathrm{Rt}=$ sum of the height of the maximum peak of the profile and the depth of the maximum valley of the profile, over the extension evaluated. $\mathrm{Rd}=$ radial face; $\mathrm{Tg}=$ tangential face.

in Figure 1, it can be observed that the anatomic elements arrangement (rays in the horizontal and vessels in the vertical) implies a not as fine texture, which confirms the highest mean roughness $\left(R_{\mathrm{a}}\right)$ on the radial face. With respect to the tangential face, more evident vessels, vertically disposed, can be observed in Figure 1, resulting in a higher $R_{\mathrm{z}}$ value, as it is related to the presence of deeper valleys of the profile analyzed. A similar behavior was presented by Trattinnickia burserifolia, whose radial face presented $R_{\mathrm{a}}$ higher than the tangential face. There was no significant difference among radial and tangential faces for the other species.

The species mean roughness $\left(R_{\mathrm{a}}\right)$ ranged from 2.41 to $7.85 \mu \mathrm{m}$, and according to the available literature related to this subject, it is possible to observe that the species studied present low roughness when their surface is flattened. The roughness variables means obtained are lower than those found by
Burdurlu et al. (2005) and Martins et al. (2011) studying Populus nigra L. and Eucalyptus benthamii Maiden \& Cambage under the same conditions, 8.84 $\mu \mathrm{m}$ and $9.08 \mu \mathrm{m}$, respectively; and by Buyuksari et al. (2010) studying Pinus nigra L. and Fagus orientalis L strand boards.

It was possible to observe through regression analysis that there is correlation between the surface mean roughness $\left(R_{\mathrm{a}}\right)$ and the density of the woods (Figure 2). Although the coefficient of determination was relatively low $\left(\mathrm{R}^{2} \approx 0.35\right)$, it was highly significant, indicating a clear trend in the data, which corroborates Cruz (2006). Wood density and porosity are inversely correlated properties. Therefore, porosity is lower when density is higher, implying a finer and, thus, not as rough texture. However, wood grain must also be analyzed, once it greatly affects wood workability and surface qualities. 


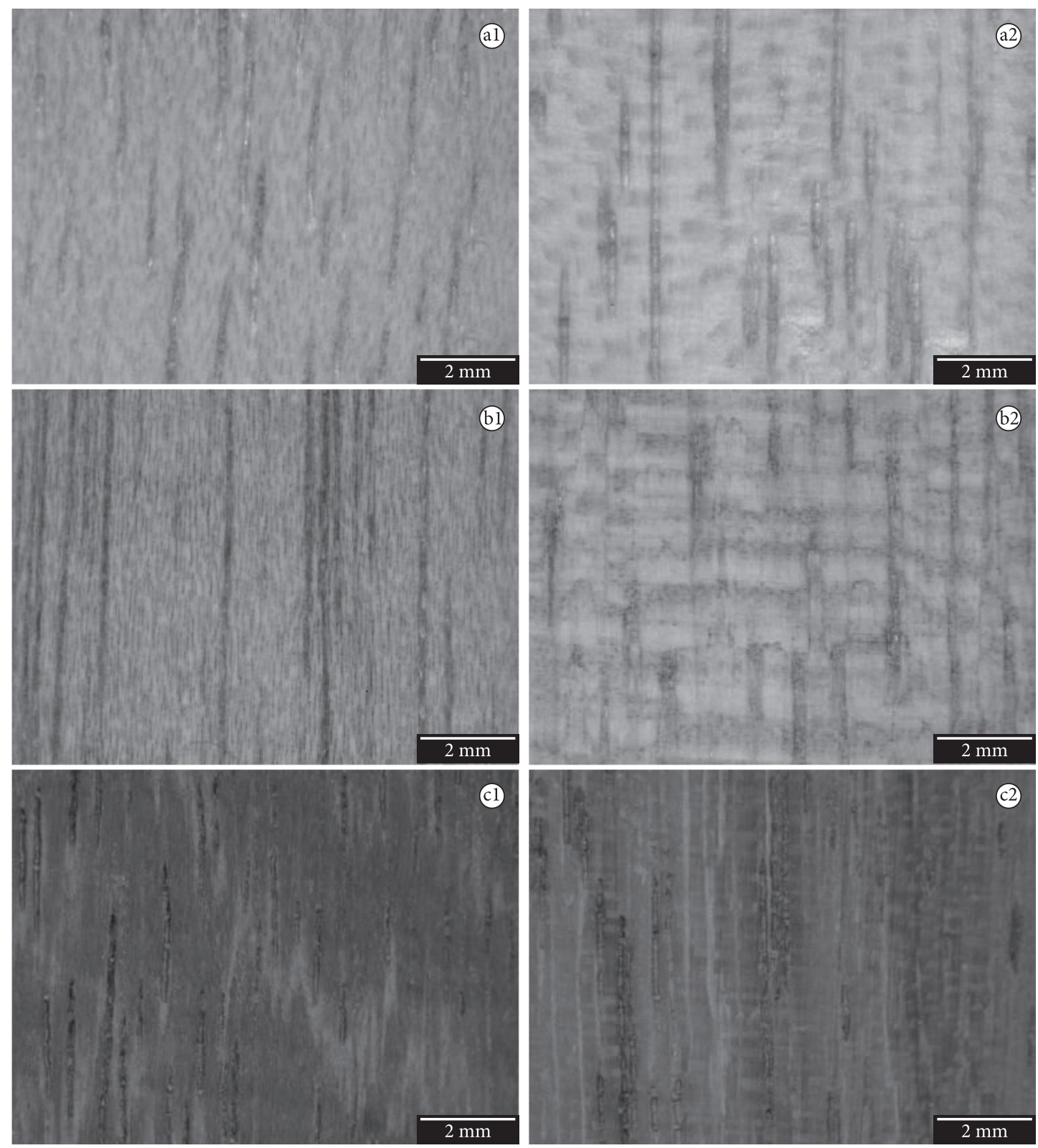

Figure 1. Images of the tangential (1) and radial (2) faces of the species Trattinnickia burserifolia (a), Virola michelii (b), and Chamaecrysta scleroxyllum (c).

\subsection{Wettability}

The values of the final contact angle, that is, after $120 \mathrm{~s}$ of both liquids are shown in Table 5 .

As wood is a heterogeneous material, there may be great variation in the results for the different species. As it can be seen in Table 5, different groups were found among the variables studied. The lowest and highest contact angles of water on both faces were found for Balizia elegans (average $6.9^{\circ}$ ) and
Rhodostemonodaphne dioica $\left(48.7^{\circ}\right)$, respectively. With respect to the adhesive, the species Protium sagotianum presented the highest wettability on both faces (Tg: 61.9 ; Rd: 59.6 ${ }^{\circ}$ ), while Terminalia glabrescens showed the lowest wettability on the radial face $\left(80.4^{\circ}\right)$ and Qualea dinizii, on the tangential face $\left(81.4^{\circ}\right)$. It was also observed that, with respect to water, there is no clear trend that differs the radial and tangential faces, whose mean values, considering all the species studied, were very similar: $30.7^{\circ}(\mathrm{Rd})$ 
Table 5. Mean values of the final contact angle $\left(\theta_{\mathrm{A}}\right)$ obtained for each species studied for water and phenolformaldehyde adhesive.

\begin{tabular}{|c|c|c|c|c|}
\hline \multirow{2}{*}{ Species } & \multicolumn{2}{|c|}{$\boldsymbol{\theta}_{\mathrm{A}}$ Water } & \multicolumn{2}{|c|}{$\theta_{\mathrm{A}}$ Adhesive } \\
\hline & Rd & $\mathrm{Tg}$ & Rd & $\mathrm{Tg}$ \\
\hline Swartzia laurifolia & $\begin{array}{l}39.71^{\mathrm{de}} \\
(3.92)\end{array}$ & $\begin{array}{l}40.85^{\mathrm{def}} \\
(6.52)\end{array}$ & $\begin{array}{l}63.92^{\mathrm{ab}} \\
(2.83)\end{array}$ & $\begin{array}{l}65.69^{\mathrm{ab}} \\
(7.12)\end{array}$ \\
\hline Brosimum sp. & $\begin{array}{l}27.12^{\mathrm{bcA}} \\
(5.63)\end{array}$ & $\begin{array}{l}22.57^{\mathrm{bB}} \\
(4.01)\end{array}$ & $\begin{array}{l}69.65^{\mathrm{bcd}} \\
(10.50)\end{array}$ & $\begin{array}{l}72.56^{\text {bcd }} \\
(6.85)\end{array}$ \\
\hline C. scleroxyllum & $\begin{array}{l}44.79^{\mathrm{efA}} \\
(3.60)\end{array}$ & $\begin{array}{l}35.84^{\text {cdeB }} \\
(3.22)\end{array}$ & $\begin{array}{l}70.11^{\mathrm{bcd}} \\
(5.00)\end{array}$ & $\begin{array}{l}71.98^{\mathrm{bcd}} \\
(4.09)\end{array}$ \\
\hline Balizia elegans & $\begin{array}{r}7.31^{\mathrm{a}} \\
(4.20)\end{array}$ & $\begin{array}{r}6.52^{\mathrm{a}} \\
(3.71)\end{array}$ & $\begin{array}{l}74.49^{\text {cde }} \\
(3.45)\end{array}$ & $\begin{array}{l}76.55^{\text {cde }} \\
(3.03)\end{array}$ \\
\hline Virola michelii & $\begin{array}{l}19.03^{\mathrm{bA}} \\
(7.87)\end{array}$ & $\begin{array}{l}7.67^{\mathrm{aB}} \\
(5.82)\end{array}$ & $\begin{array}{l}77.63^{\mathrm{deB}} \\
(3.21)\end{array}$ & $\begin{array}{l}81.77^{\mathrm{eA}} \\
(3.09)\end{array}$ \\
\hline T. burserifolia & $\begin{array}{c}16.97^{\mathrm{ab}} \\
(11.14)\end{array}$ & $\begin{array}{l}19.89^{\mathrm{b}} \\
(8.88)\end{array}$ & $\begin{array}{l}72.89^{\text {bcde }} \\
(4.74)\end{array}$ & $\begin{array}{l}74.14^{\text {cde }} \\
(6.06)\end{array}$ \\
\hline T. myrmecophila & $\begin{array}{c}20.11^{\mathrm{b}} \\
(6.81)\end{array}$ & $\begin{array}{c}26.30^{\mathrm{bc}} \\
(11.54)\end{array}$ & $\begin{array}{l}67.30^{\mathrm{abc}} \\
(8.67)\end{array}$ & $\begin{array}{l}68.85^{a b c} \\
(6.22)\end{array}$ \\
\hline R. dioica & $\begin{array}{c}50.62^{f} \\
(10.40)\end{array}$ & $\begin{array}{c}46.89^{f} \\
(12.92)\end{array}$ & $\begin{array}{l}73.10^{\text {cde }} \\
(8.94)\end{array}$ & $\begin{array}{l}77.59^{\mathrm{de}} \\
(7.54)\end{array}$ \\
\hline Qualea dinizii & $\begin{array}{c}44.09^{\mathrm{ef}} \\
(11.86)\end{array}$ & $\begin{array}{l}46.08^{\text {ef }} \\
(9.55)\end{array}$ & $\begin{array}{l}76.88^{\text {de }} \\
(5.23)\end{array}$ & $\begin{array}{l}81.34^{e} \\
(2.70)\end{array}$ \\
\hline T. glabrescens & $\begin{array}{l}42.62^{\text {def }} \\
(7.01)\end{array}$ & $\begin{array}{c}46.10^{\text {ef }} \\
(10.01)\end{array}$ & $\begin{array}{l}80.44^{\mathrm{e}} \\
(2.92)\end{array}$ & $\begin{array}{l}76.19^{\text {cde }} \\
(5.93)\end{array}$ \\
\hline Protium sagotianum & $\begin{array}{l}32.78^{\mathrm{cd}} \\
(5.83)\end{array}$ & $\begin{array}{c}34.32^{\mathrm{cd}} \\
(4.27)\end{array}$ & $\begin{array}{c}59.59^{\mathrm{a}} \\
(14.14)\end{array}$ & $\begin{array}{r}61.68^{\mathrm{a}} \\
(11.52)\end{array}$ \\
\hline
\end{tabular}

The values in parenthesis represent the standard deviation; means followed by the same letter do not statistically differ from each other by Tukey's test $(p \leq 0.05)$. Lower case letters regard the mean separation test between species and capital letters regard the analysis between the radial and tangential faces within each species. $\mathrm{Rd}=$ radial face; $\mathrm{Tg}=$ tangential face.

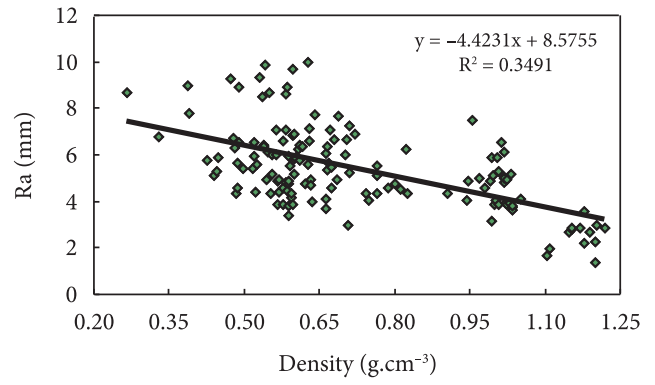

Figure 2. Relationship between mean roughness values (Ra) of the surface and the apparent density of wood.

and $30.3^{\circ}(\mathrm{Tg})$. On the other hand, concerning the phenol-formaldehyde adhesive, the radial face presented a small trend for better wettability than the tangential face: $71.5^{\circ}$ vs $73.5^{\circ}$. Nevertheless, it can be inferred from these results that the wood faces did not affect wood wettability consistently. Shupe et al. (2001), investigating the wettability of 22 American hardwoods found similar results; they demonstrated that the tangential and radial faces have relatively similar anatomical composition.
Based on the ANOVA results, Brosimum sp., Chamaecrysta scleroxyllum, and Virola michelii presented higher final contact angles on the radial face than on the tangential face when water was used as liquid. This indicates that the tangential face presents better wettability within these three species. If we relate the highest $R_{z}$ parameter value (five highest peaks and five deepest valleys) on the tangential face of Virola micheliia to this result, it is possible to infer that the presence of vessels and tops of rays may have facilitated water penetration and improved wettability on this face. A similar explanation can be used for Brosimum sp. and Chamaecrysta scleroxyllum. In fact, Lee et al. (2007) mentioned that superficial roughness is very heterogeneous due to the cellular structure of the wood and the type of grain, therefore affecting wettability.

Nevertheless, when the phenol-formaldehyde adhesive was used as liquid, there were differences between the faces only for Virola michelii, where the 
radial face presented lower final contact angles than the tangential face: $77.6^{\circ}$ vs $81.8^{\circ}$. As discussed in the previous item, Virola michelii presented higher mean roughness $\left(R_{\mathrm{a}}\right)$ on the radial face, which may have facilitated the adhesive spreading, resulting in a lower final contact angle. Furthermore, on the radial face, the rays are disposed horizontally forming a path that enables, thus, higher fluidity of the adhesive on the wood surface. Therefore, this anatomical disposition may have contributed for the best spreading of the adhesive, whose superficial tension and viscosity are very different from water. Even though there was no significant difference among the faces for the other species studied, as mentioned previously, the radial face, in general, tended to be more wettable than the tangential face for the phenol-formaldehyde adhesive.

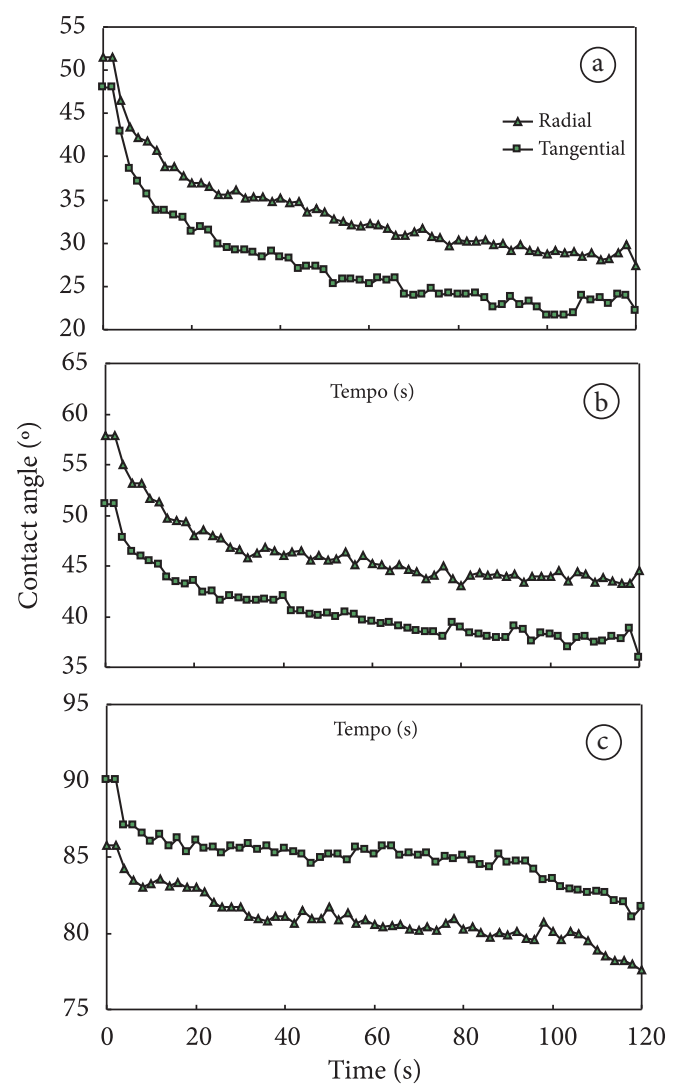

Figure 3. Variation of the contact angle over time in the wood of Brosimum sp. (a) and Chamaecrysta scleroxyllum (b) for water; and in the wood of Virola michelli (c) for the phenol-formaldehyde adhesive, in the radial and tangential faces.
Figure 3 shows the evolution of the contact angle for water and the phenol-formaldehyde adhesive on the radial and tangential faces. According to Sheldon et al. (2001), the initial stage, known as spreading stage, occurs when the contact angle decreases fast; however, throughout time, the contact angle reduces slowly and finally reaches the equilibrium, the diffusion stage. Based on this concept, it can be observed that it takes longerfor water to reach the diffusion stage, which occurs at around $30 \mathrm{~s}$, while the equilibrium for the phenolformaldehyde adhesive is reached before 20 seconds. According to Cruz (2006), this behavior results from the anatomy of wood and it is influenced by its properties, as well as by the properties of resins such as viscosity and superficial tension. Lee et al. (2007), studying the wettability of Pinus taeda L., observed that urea-formaldehyde and phenol-formaldehyde resins gelatinize fast, making the spreading difficult, which can explain the fastness at which the diffusion point is reached.

For all the species studied, the contact angle was lower for water than for the adhesive (average $33.9^{\circ}$ vs $72.5^{\circ}$ ), which presents greater viscosity and superficial tension. There is clear difference among the contact angle values between water and phenol-formaldehyde, which was also observed by Brisolari (2008), who compared wettability of softwood and hardwood using water and ethylene glycol. According to $\mathrm{Lu} \& \mathrm{Wu}$ (2005), $72 \%$ of the species studied presented contact angle values for the adhesive similar to those found for Liriodendron tulipifera L. wood sheets, thermally treated and submitted to wettability test with water after a 45 -seconds exposition, the same was found in the study by Ayrilmis et al. (2009), who analyzed the contact angle on solid wood, plywood, and laminated veneer lumber (LVL).

Regression analysis was carried out in order to verify the existence of relation between surface roughness and wood wettability. According to this analysis, there was no correlation between these properties; therefore, it is possible to state that, in the study conditions, roughness did not consistently influence the wettability of the species analyzed. Shupe et al. (2001) inferred the same after studying the wettability of sanded and non-sanded surfaces of 22 wood species. Nevertheless, our results differ from 


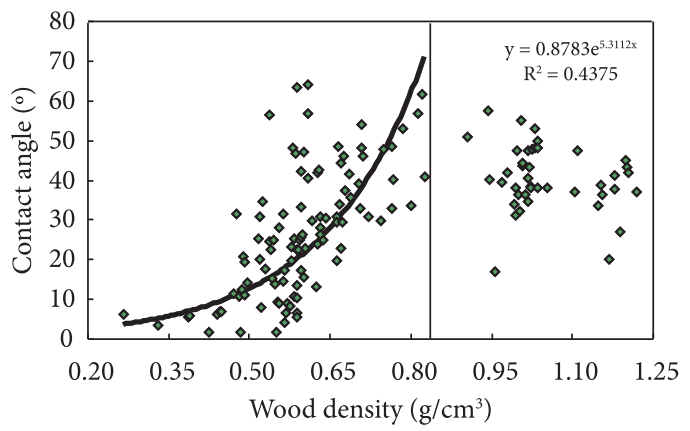

Figure 4. Relation between wood density and final contact angle $\left(\theta_{\mathrm{A}}\right)$ for water.

Arnold (2010), who found that the contact angle is lower when roughness is higher and, consequently, wood wettability is higher.

Regression analysis to evaluate the relation between density and mean contact angle (radial and tangential) was also performed. Although the regression presented $\mathrm{R}^{2}=0.43$, the relation between variables was statistically significant. Figure 4 shows that until nearly $0.85 \mathrm{~g} \mathrm{~cm}^{-3}$ density, the final contact angle keeps rising and, consequently, indicating lower wettability of these species. From this point, the contact angle reaches the top and the values do not vary significantly. Denser wood species usually present higher durability than lighter wood species, mainly because of the toxic compound of extractives. Since it is well known that wood extractives play an important role on wood wettability (Santoni \& Pizzo, 2011), it could be inferred that, above this density value, the extractive nature and quantity might affect wettability, which is also reduced because of the fine texture of those denser woods. Nevertheless, not only the amount of extractive should be taken into account, but also fatty acids and phenolic compounds (Santoni \& Pizzo, 2011).

The results herein verified differ from those obtained by other authors. Kishino \& Nakano (2004) studied the wettability of eight tropical woods with density ranging from 0.69 to $1.14 \mathrm{~g} \mathrm{~cm}^{-3}$ and found no clear trend between wood density and wettability. They explained that wettability is affected by the surface structure and surface chemical composition. Likewise, Boehme \& Hora (1996) could not find a mathematical relation between wood density and wettability of 40 wood species from North American, European and tropical regions.

\section{CONCLUSIONS}

Significant differences between the species studied were identified concerning wettability and superficial roughness. The difference between the faces was more evident for wettability, whose radial face tended to be more wettable for the phenolformaldehyde adhesive. For water, both faces presented the same trend for wettability. Surface roughness did not consistently affect the wettability of the species studied. Significant reduction trend was observed for wettability and roughness with the increase of wood density. As an initial study, the performance of further evaluations with respect to the wettability of other Amazonian species is suggested so that suitable information to draw a correct profile of the behavior of this type of material could be obtained.

\section{ACKNOWLEDGEMENTS}

To the National Council for Scientific and Technological Development (CNPq); to the Coordination for the Improvement of Higher Education Personnel (CAPES); to the Foundation for Research Support in the State of Amazonas (FAPEAM) for the financial support in equipment acquisition through the National Institute of Science and Technology of Amazonian Timber (INCT); to the Federal University of Western Pará (UFOPA), for providing the woody material; and to Schenectady Crios S/A for the donation of the phenol-formaldehyde adhesive.

\section{SUBMISSION STATUS}

Received: 19/08/2012

Accepted: 24/01/2013

Published: 28/02/2013

\section{CORRESPONDENCE TO}

\section{Cláudio Henrique Soares Del Menezzi}

Departamento de Engenharia Florestal,

Universidade de Brasília - UnB,

Brasília, DF, Brasil

e-mail: cmenezzi@unb.br 


\section{REFERENCES}

Arnold M. Planing and Sanding of Wood Surfaces - Effects on Surface Properties and Coating Performance. In: Proceedings PRA's 7th International Woodcoatings Congress; 2010; Middlesex. Middlesex: Hampton; 2010.

Ayrilmis N, Dundar T, Candan Z, Akbulut T. Wettability of fire retardant treated laminated venner lumber (LVL) manufactured from veneers dried at different temperatures. BioResources 2009; 4: 1536-1544.

Boehme C, Hora G. Water absorption and contact angle measurement of native European, North American and tropical wood species to predict gluing properties. Holzforschung 1996; 50: 269-276. http://dx.doi. org/10.1515/hfsg.1996.50.3.269

Brisolari A. Estudo da molhabilidade em madeiras tropicais ou de reflorestamento por medidas de ângulo de contato e de permeabilidade [dissertação]. São Carlos: Universidade Federal de São Carlos, Universidade de São Paulo; 2008.98 p.

Burdurlu E, Usta I, Ulupinar M, Aksu B, Erarslan Ç. The effect of the number of blades and grain size of abrasives in planning and sanding on the surface roughness of European black pine and Lombardy poplar. Turkish Journal of Agriculture \& Forestry 2005; 25: 315-321.

Buyuksari U, Akbulut T, Guler C, As N. Wettability and surface roughness of natural and plantation-grown narrow-leaved (Fraxinus angustifolia Vahl.) wood. BioResources 2011; 6: 4721-4730.

Buyuksari U, Avci E, Ayrilmis N, Akkilic H. Effect of pine cone ratio on the wettability ad surface roughness of particleboard. BioResources 2010; 5: 1824-1833.

Campos MBS, Del Menezzi CHS, Souza MR. Flexural properties of wood I-beams flanged with tropical hardwoods. Journal of Tropical Forest Science 2012; 24: 359-368.

Clement CR, Higuchi N. A floresta amazônica e o futuro do Brasil. Ciência e Cultura 2006; 58: 44-49.

Comissión Panamericana de Norma Técnicas - COPANT. COPANT 30:1-004: Maderas: método de determinación del peso especifico aparente. Caracas: COPANT; 1971. 7 p.

Cruz MMS. Estudo da molhabilidade da madeira de pinho pela resina ureia-formaldeído [dissertação]. Lisboa: Instituto Superior de Agronomia da Universidade Técnica de Lisboa; 2006. 200 p.

Del Menezzi CHS, Silveira RR, Souza MR. Estimativa das propriedades de flexão estática de seis espécies de madeiras amazônicas por meio da técnica não-destrutiva de ondas de tensão. Acta Amazonica 2010; 40: 325-332. http://dx.doi.org/10.1590/S0044-59672010000200011
Freeman HA, Wangaard FF. Effect of wettability of wood on glue-line behavior of two urea resins. Forest Products Journal 1960; 9(12): 451-458.

Frihart CR. Wood Adhesion and Adhesives. In: Rowell RM. Handbook of wood chemistry and wood composites. New York: CRC Press; 2005. p. 215-275.

Gray VR. The wettability of wood. Forest Products Journal 1962; 12(9): 452-461.

Iwakiri S, Vianez BF, Weber C, Trianoski R, Almeida VC. Avaliação das propriedades de painéis aglomerados produzidos com resíduos de serrarias de nove espécies de madeiras tropicais da Amazônia. Acta Amazonica 2012; 42: 59-64. http://dx.doi.org/10.1590/ S0044-59672012000100007

Kamke FA, Lee JN. Adhesive penetration in wood - A Review. Wood and Fiber Science 2007; 39: 205-220.

Kishino M, Nakano T. Artificial weathering of tropical woods. Part 1: Changes in wettability. Holzforschung 2004; 58: 552-557.

Lee S, Shupe TF, Groom LH, Hse CY. Wetting behaviors of phenol- and urea-formaldehyde resins as compatibilizers. Wood and Fiber Science 2007; 39: 482-492.

Lemaster RL, Taylor JB., High Speed Surface Assessment of Wood and Wood-Based Composites. In: Proceedings of the 14th Wood Machining Seminar; 1999, France. France; 1999. p. 479-488.

Lu JZ, Wu Q. Surface and interfacial characterization of wood-PVC composite: imaging morphology and wetting behavior. Wood and Fiber Science 2005; 37: 95-111.

Malkoçoglu A. Machining properties and surface roughness of various wood species planed in different conditions. Building and Environment 2007; 42: 2562-2567. http://dx.doi. org/10.1016/j.buildenv.2006.08.028

Marra AA. Technology of wood bonding: principles and practice. Nova Iorque: Van Nostrand Reinhold; 1992. 454 p.

Martins SA, Ferraz JM, Santos CMT, Del Menezzi CHS, Souza MR. Efeito da usinagem na rugosidade da superfície da madeira de Eucalyptus benthamii Maiden et Cambage. Floresta e Ambiente 2011; 18: 135-143. http://dx.doi.org/10.4322/floram.2011.031

Oliveira RM, Brisolari A, Sales A, Gonçalves D. Wettability, shrinkage and color changes of Araucaria angustifolia after heating treatment. Materials Research 2010; 13: 351-354. http://dx.doi.org/10.1590/ S1516-14392010000300012

Piao C, Winandy JE, Shupe TF. From hydrophilicity to hydrophobicity: a critical review: Part I. Wettability and surface Behavior. Wood and Fiber Science 2010; 42: 490-510. 
Sheldon S, Gardner D. Dynamic adhesive wettability of wood. Wood and Fiber Science 2001; 33: 58-68.

Santoni I, Pizzo B. Effect of surface conditions related to machining and air exposure on wettability of different Mediterranean wood species. International Journal of Adhesion and Adhesives 2011; 31: 743-753. http:// dx.doi.org/10.1016/j.ijadhadh.2011.07.002

Santos CMT, Del Menezzi CHS, Souza MR. Properties of thermo-mechanically treated wood from Pinus caribaea var. hondurensis. BioResources 2012; 7: 1850-1865.

Santos CMT, Del Menezzi CHS. Efeito da gramatura sobre a resistência ao cisalhamento de linha de cola de duas madeiras tropicais: seru (Allantoma lineata) e marupá (Simarouba amara). Floresta 2010; 40: 345-354.

Shupe TF, Hse CY, Wang WH. An investigation of selected factors that influence hardwood wettability. Holzforschung 2001; 55: 541-548. http://dx.doi. org/10.1515/HF.2001.087

Sinn G, Sandak J, Ramananatoandro T. Properties of wood surfaces - characterisation and measurement. A review. Holzforschung 2009; 63: 196-203. http://dx.doi. org/10.1515/HF.2009.016

Soares AC, Oliveira RM, Brisolari A, Sales A, Gonçalves D. Molhabilidade em amostras de Araucaria angustifolia e Pinus elliottii após tratamento térmico e envelhecimento. Scientia Forestalis 2011; 39: 447-456.

Teles RF, Del Menezzi CHS, Souza MR, Souza F. Effect of nondestructive testing of laminations on the bending properties of glulam beams made from louro-vermelho (Sextonia rubra). Cerne 2010; 16: 77-85.

Teles RF, Del Menezzi CHS, Souza MR, Souza F. Nondestructive evaluation of a tropical hardwood: interrelationship between methods and physicalacoustical variables. Ciência da Madeira 2011; 2:1-14.

Wålinder M. Wetting phenomena on wood: factors influencing measurements of wood wettability [thesis]. Stockholm: Royal Institute of Technology; 2000. 70 p.

Wålinder M. Study of Lewis acid-base properties of wood by contact angle analysis. Holzforschung 2002; 56: 363-371. 